\title{
The New Pythagorean Equation that Applies to all Types of Lines
}

\section{Sigit Haryadi}

Institut Teknologi Bandung - Indonesia

sigit@ haryadi.org

Paper DOI 10.31227/osf.io/umxq3

Citations

APA: Haryadi, S. (2019, January 15). The New Pythagorean Equation that Applies to all Types of Lines. Retrieved from osf.io/preprints/inarxiv/umxq3

MLA: Haryadi, Sigit. "The New Pythagorean Equation That Applies to All Types of Lines." INARxiv, 15 Jan. 2019. Web.

Chicago: Haryadi, Sigit. 2019. "The New Pythagorean Equation That Applies to All Types of Lines." INA-Rxiv. January 15. osf.io/preprints/inarxiv/umxq3.

\begin{abstract}
This working paper proposes a new Pythagorean equation that applies to all types of lines, which the straight lines, curved lines, broken lines and so on, where, the formula will turn into the existing formula if used in the straight lines. Specifically, this equation is very accurate and precise because it implements the concept of Harmony in Gradation-the Formula for Everything. Therefore, the new equation will be very useful for researchers in the fields of physics, biological sciences, and social sciences because, in the reality, we will often encounter a phenomenon which is represented by various types of lines including a straight line.
\end{abstract}

Keywords: New Pythagorean Equation; Pythagorean Theorem; Harmony in Gradation-the formula for everything; Pythagorean equilibrium.

\section{Background}

In fact, we are often faced with a non-straight line, whether it is a curved line or a broken line. For example, imagine you move straight eastward, from where you are somewhere on the equator, around the earth, then someday you will appear straight from the west to where you originally were, and the track that you think is a collection of several the straight line, it turns out to be an arch. The second example, you make a curve of the exchange rate of the US dollar against the Chinese Yuan for five consecutive days, then you will most likely get five broken lines. The last example, you want to make your body temperature curve with accuracy onehundredth of a degree, then you will get a large set of the broken lines. In the three examples above, it is very possible that we are very sure that the phenomenon we observe is fulfilling the Pythagorean equation for two or three parameters as the independent variable.

Here, we offer a new concept for applying the Pythagorean Theorem to various types of lines including a straight line, where the equation should change to the general Pythagorean equation when used in a single straight line. 


\section{Proposed Equation}

Proposed Non - Straight Line Equatian:

$$
\left.\sum_{i=1}^{N}\left\{\frac{d s_{i}^{2} /\left(d x_{i}^{2}+d y_{i}^{2}+d z_{i}^{2}\right)}{\sum\left\{d s_{i}^{2} /\left(d x_{i}^{2}+d y_{i}^{2}+d z_{i}^{2}\right)\right.}\right\}\right\}^{2}+\sum_{i=1}^{N} \sum_{j=1}^{N}\left\{\frac{d s_{i}^{2} /\left(d x_{i}^{2}+d y_{i}^{2}+d z_{i}^{2}\right)}{\sum\left\{d s_{i}^{2} /\left(d x_{i}^{2}+d y_{i}^{2}+d z_{i}^{2}\right)\right.}-\frac{d s_{j}^{2} /\left(d x_{j}^{2}+d y_{j}^{2}+d z_{j}^{2}\right)}{\sum\left\{d s_{j}^{2} /\left(d x_{j}^{2}+d y_{j}^{2}+d z_{j}^{2}\right)\right\}}\right\}^{2} ; i>j=1 / N
$$

If $\mathrm{s}$ is a straight line, then $\mathrm{N}=1$ and equation 1 will turn to the following equation:

$$
d s^{2}=d x^{2}+d y^{2}+d z^{2}
$$

If a system does not meet equation 1 , in the sense that the system does not have a perfect Pythagorean equilibrium, then the Pythagorean equilibrium level can be calculated using the following equation:

Pythagorean Equilibrium $\leq 1=$

$1 / N * \sum_{i=1}^{N}\left\{\frac{d s_{i}^{2} /\left(d x_{i}^{2}+d y_{i}^{2}+d z_{i}^{2}\right)}{\sum\left\{d s_{i}^{2} /\left(d x_{i}^{2}+d y_{i}^{2}+d z_{i}^{2}\right)\right.}\right\}^{2}+\sum_{i=1}^{N} \sum_{j=1}^{N}\left\{\frac{d s_{i}^{2} /\left(d x_{i}^{2}+d y_{i}^{2}+d z_{i}^{2}\right)}{\sum\left\{d s_{i}^{2} /\left(d x_{i}^{2}+d y_{i}^{2}+d z_{i}^{2}\right)\right.}-\frac{d s_{j}^{2} /\left(d x_{j}^{2}+d y_{j}^{2}+d z_{j}^{2}\right)}{\sum\left\{d s_{j}^{2} /\left(d x_{j}^{2}+d y_{j}^{2}+d z_{j}^{2}\right)\right\}}\right\}^{2} ; i>j$

\begin{tabular}{|c|c|c|c|c|c|c|c|}
\hline $\mathbf{i}, \mathbf{j}$ & $\mathrm{dx}^{2}$ & $\mathbf{d y}^{2}$ & $\mathrm{dz}^{2}$ & $\begin{array}{l}d s^{2} \text { of the } \\
\text { System A }\end{array}$ & $\begin{array}{l}\mathrm{ds}^{2} \text { of the } \\
\text { System B }\end{array}$ & $\begin{array}{l}\text { Calculation uses Existing } \\
\text { Pythagorean Equation }\end{array}$ & $\begin{array}{l}\text { Calculation uses Proposed } \\
\text { Pythagorean Equation }\end{array}$ \\
\hline 1 & 1 & 1 & 1 & 3 & 3.6 & \multirow{4}{*}{$\begin{array}{l}\text { System A fulfills, but system B } \\
\text { does not meet the existing } \\
\text { Pythagorean equation }\end{array}$} & \multirow{4}{*}{$\begin{array}{l}\text { Both systems A and B meet the } \\
\text { new Pythagorean equation } \\
\text { proposed in this working paper }\end{array}$} \\
\hline 2 & 1 & 1 & 2 & 4 & 4.8 & & \\
\hline 3 & 1 & 2 & 2 & 5 & 6 & & \\
\hline 4 & 2 & 2 & 2 & 6 & 7.2 & & \\
\hline
\end{tabular}

\section{Calculation Example}

\section{CLOSING}

This working paper, not only contains the new insight, but also provides homework for all researchers in the world to review the existing formulas they use today, starting with the formula used that causes the research being carried out to have a deadlock. Signs that your formula must be corrected are when decades of theory appear dubious when faced with another theory, or when years of research do not find the right solution. And, more obvious signs are when practitioners begin to question the theories made by academics. 


\section{Reference}

1. Haryadi, S. (2018, December 20). Hundreds of Years We Live With Mathematical Formulas That Are Only "Half -Correct". Retrieved from osf.io/preprints/inarxiv/a7ws9

2. Sigit Haryadi. (2017). Haryadi Index and Its Applications in Science of Law, Sociology, Economics, Statistics, and Telecommunications. Penerbit Elex Media Komputindo. Jakarta. ISBN: 978-602-02-9895-5.

3. Haryadi, S. (2018, December 6). The Fundamental of Harmony in Gradation, the Formula for Everything. Retrieved from osf.io/preprints/inarxiv/z2rvj

4. Sigit Haryadi. (2017). The Fairness over Inequality Index: Unfairness is Disaster - a notebook of Sigit Haryadi. Researchgate. DOI: 10.13140/RG.2.2.34379.49449.

5. Haryadi, S. (2018, March 17). The Ten First Implementations to prove that "The Harmony in Gradation" is "The Formula Everything". Retrieved from osf.io/preprints/inarxiv/59szb

6. Sigit Haryadi. (March 17, 2018). The Six 100-year-old Formula Should be Replaced. Researchgate. DOI 10.13140/RG.2.2.21919.66723

7. Haryadi, S. (2018, December 12). A New Postulate for Using the Harmony in Gradation to Finding the Theory of Everything. Retrieved from osf.io/preprints/inarxiv/2rak6

8. Sigit Haryadi. (2017). Indeks Haryadi dan Penerapan di Ilmu Hukum, Sosiologi, Ekonomi, Statistik, dan Telekomunikasi. Penerbit Elex Media Komputindo, Jakarta. ISBN: 978-602-02-9896-2

9. Sigit Haryadi. (2016). Haryadi Index for Competition, Equality and Correlation Evaluation. Penerbit Lantip Safari Media, Bandung, Indonesia. ISBN: 978-602-73231-3-2

10. Sigit Haryadi. (2016). Haryadi Index untuk Evaluasi Kompetisi, Kesetaraan dan Korelasi. Penerbit Lantip Safari Media, Bandung, Indonesia. ISBN: 978-602-73231-3-1

11. Haryadi, S. (2018, March 29). Estimasi Cerdas Ver-H.1.0. http://doi.org/10.17605/OSF.IO/DHQ9Y

12. Haryadi, S. (2018, March 29). Smart Estimation Ver-H.1.0. http://doi.org/10.17605/OSF.IO/2TYQK

13. Haryadi, S. (2018, March 17). Sepuluh Implementasi Yang Pertama untuk Membuktikan bahwa "The Harmony in Gradation" adalah "The Formula Everything". Retrieved from osf.io/preprints/inarxiv/ja9ve

14. Haryadi, S., \& California, S. H. (2018, March 14). New Method to Calculate the Level of Consistency of the Pauli \& Kraepelin Tests. Retrieved from osf.io/preprints/inarxiv/ty326

15. Haryadi, S., \& California, S. H. (2018, March 14). Metoda Baru Untuk Menghitung Tingkat Konsistensi pada Tes Pauli \& Kraepelin. Retrieved from osf.io/preprints/inarxiv/qht8j

16. Haryadi, S. (2018, March 6). Calculation the Equity Level of an Internet Service. Retrieved from osf.io/uzcmq

17. Haryadi, S. (2018, March 6). Perhitungan Tingkat Pemerataan Layanan Internet. Retrieved from osf.io/preprints/inarxiv/rgct3

18. Dyah Rakhma Ariyanti; Sigit Haryadi. (October 2017). Analysis of Harmony in Gradation Index on 5G Cellular Network Quantitative Analysis. The 11th International Conference on Telecommunication Systems, Services, and Applications, At Lombok, Indonesia.

19. Haryadi, S. (2017, November). Probabilitas Statistik Untuk Insinyur. Researchgate. DOI: 10.13140/RG.2.2.14304.58885

20. Haryadi, S. (2018, February 1). Indeks Haryadi dan Prospeknya Untuk Menjadi Suatu "Formula of Everything (versi 31 Desember 2017). Retrieved from osf.io/zex45

21. Haryadi, S. (2018, February 1). KALKULATOR untuk membuat Regresi Linier Tanpa Intersep. Retrieved from osf.io/emvs7

22. Haryadi, S. (2018, February 1). Kalkulator Untuk Mengukur Tingkat Kompetisi di suatu Industri, dengan menggunakan rumus Indeks Haryadi. Retrieved from osf.io/fy7zu

23. Haryadi, S. (2018, February 17). Calculation the Competition Levels between Students in Class and the Relation to the Teacher or Lecture Fairness in Teaching. Researchgate. DOI: 10.13140/RG.2.2.30359.06569

24. Haryadi, S. (2018, February 17). Perhitungan Tingkat Kompetisi antar Murid atau Mahasiswa di Kelas dan Kaitannya Dengan Keadilan Guru atau Dosen Dalam Mengajar. Retrieved from osf.io/a894w

25. Haryadi, S. (2018, February 22). Equality Correlation Calculation. Researchgate. DOI: 10.13140/RG.2.2.22068.76168

26. Haryadi, S. (2018, February 22). Kalkulator Untuk Menghitung Korelasi Kesetaraan. Retrieved from osf.io/preprints/inarxiv/7r9jy

27. Haryadi, S. (2018, February 24). Calculation of "Channel Cavity" on Data Communications. Equality Correlation Calculation. Research gate. DOI: 10.13140/RG.2.2.30536.01288

28. Haryadi, S. (2018, February 24). Perhitungan "Rongga Kanal" pada Komunikasi Data. Retrieved from osf.io/preprints/inarxiv/y3wcg

29. Haryadi, S. (2018, February 7). Statistik Terapan: Pengujian Regulasi \& Kebijakan Telekomunikasi. Retrieved from osf.io/3pkfw

30. Haryadi, S. (2018, January 26). Chapter 2 of Network Performance and Quality of Service: Determination of Key Performance Indicator (KPI). Retrieved from osf.io/preprints/inarxiv/6gtnd 
31. Haryadi, S., \& Riani, W. (2018, March 5). METODE PENETAPAN TARIF PAJAK PENGHASILAN YANG BERKEADILAN. Retrieved from osf.io/preprints/inarxiv/ayg58

32. Nie Levin Kusuma Adiatma; Sigit Haryadi. (2017, October). Comparison of the Haryadi Index with Existing Method in Competition, Equality, Fairness, and Correlation Level Calculation Case Study: Telecommunication Industry. The 11th International Conference on Telecommunication Systems, Services, and Applications, At Lombok, Indonesia.

33. Sigit Haryadi. (2017). Calculation of the Mobile Communication Competition using Haryadi Index. DOI: 10.13140/RG.2.2.15634.25280

34. Sigit Haryadi. (2017). Harmony in Gradation and its prospects as the Formula of Everything (First edition of posts: December 31, 2017). Researchgate. DOI: 10.13140/RG.2.2.19309.08169

35. Sigit Haryadi. (2017). the Equality Correlation Method. Researchgate. DOI: 10.13140/RG.2.2.10443.80169.

36. Sigit Haryadi. (2017). the Non-Intercept Linear Regression Method. Researchgate. DOI: 10.13140/RG.2.2.18721.71522

37. Sigit Haryadi. (2017, December). Calculator for Measurement the Competition Index \& Level. Researchgate. DOI: 10.13140/RG.2.2.23626.26568

38. Sigit Haryadi. (2017, December). Calculator for non-intercept linear regression. Researchgate. DOI: 10.13140/RG.2.2.15761.94562.

39. Sigit Haryadi. (2017, January). Calculation of the Income Equality Levels between Regions using the Haryadi Index. Researchgate. DOI: 10.13140/RG.2.2.36605.77282

40. Sigit Haryadi. (2018, February). Applied Statistics for Assessment of the Regulation and Policy: case study in Telecommunication Industry. DOI: 10.13140/RG.2.2.15774.02884

41. Sigit Haryadi; Dyah Rakhma Ariyanti. (October 2017). The Fairness of Resource Allocation and Its Impact on 5G Ultra-Dense Cellular Network Performance. The 11th International Conference on Telecommunication Systems, Services, and Applications, At Lombok, Indonesia.

42. Westi Riani; Sigit Haryadi. (2017). CALCULATOR for the Government to make the Fair Policy of Tax Rates. Researchgate. DOI: 10.13140/RG.2.2.18550.50246. Available online at http://sigitharyadi.net/multidicipline/income-tax-rates-calculator-id/

43. Westi Riani; Sigit Haryadi. (2017). the Method of Tax Rate Determination Based On Fairness. Prosiding Seminar Nasional SNaPP2017, Bandung, Indonesia.

44. Haryadi, S., \& Riani, W. (2018, March 12). Telecommunication Competition and Interconnection. Retrieved from osf.io/preprints/inarxiv/7tfqd

45. Westi Riani; Sigit Haryadi. (2017). Prosiding SNaPP2017 "THE METHOD OF TAX RATE DETERMINATION BASED ON FAIRNESS". Conference: Seminar Nasional Penelitian dan PKM (SNaPP) 2017At: Bandung, Indonesia.

46. Sigit Haryadi. (2017). Tantangan Untuk Menerapkan Haryadi Index pada Ilmu Fisika. Jurnal Pendidikan Fisika Sekolah Menengah. Jurnal Pendidikan Fisika Sekolah Menengah. Vol 9 no 1 2017. ISSN: 1979-4959. Available at : https://www.researchgate.net/publication/316683866

47. Westi Riani; Sigit Haryadi. (2016). Keterbatasan Indeks Gini sebagai Ukuran Ketimpangan Pendapatan dan Solusi Metoda Alternatif. Prosiding SNaPP: Sosial, Ekonomi, dan Humaniora. Tersedia di http://proceeding.unisba.ac.id/index.php/sosial/article/view/383

48. Haryadi, S., \& Riani, W. (2018, March 19). Pengukuran Ketimpangan Indeks Pembangunan Manusia. Retrieved from osf.io/preprints/inarxiv/x9vjt

49. Haryadi, S., \& Riani, W. (2018, March 19). Measurement of the Human Development Index Inequality. Retrieved from osf.io/preprints/inarxiv/5r42m

50. Haryadi, Sigit. 2018. "Always Move to Seek Perfection: The New Equilibrium Index Calculation for the Science of Physics and Astronomy." INA-Rxiv. July 13. osf.io/preprints/inarxiv/8hrnb.

51. Sigit Haryadi. "Homepage." Harmony in Gradation: The Formula for Everything, 17th December 2018, https://www.haryadi.org/

52. Sigit Haryadi. "A New Equilibrium Index for the science of Physics and Astronomy." Harmony in Gradation: The Formula for Everything, 17th December 2018, https://www.haryadi.org/a-new-equilibrium-index/

53. Sigit Haryadi. "Formula for Everything, It's My Turn Trying to Make It." Harmony in Gradation: The Formula for Everything, 17th December 2018, https://www.haryadi.org/formula-for-everything-its-my-turntrying-to-make-it/

54. Sigit Haryadi. "Competition Level in the Industry." Harmony in Gradation: The Formula for Everything, 17th December 2018, https://www.haryadi.org/competition-level-in-the-industry/

55. Sigit Haryadi. "Competition Levels among Students." Harmony in Gradation: The Formula for Everything, 17th December 2018, https://www.haryadi.org/competition-levels-among-students-in-class/

56. Sigit Haryadi. "Consistency Test." Harmony in Gradation: The Formula for Everything, 17th December 2018, https://www.haryadi.org/consistency-test/ 
57. Sigit Haryadi. "Equality Correlation." Harmony in Gradation: The Formula for Everything, 17th December 2018, https://www.haryadi.org/equality-correlation/

58. Sigit Haryadi. "Fair Policy of Tax Rate." Harmony in Gradation: The Formula for Everything, 17th December 2018, https://www.haryadi.org/fair-policy-of-tax-rates/

59. Sigit Haryadi. "Fairness over Inequality." Harmony in Gradation: The Formula for Everything, 17th December 2018, https://www.haryadi.org/fairness-over-inequality/

60. Sigit Haryadi. "Income Equality." Harmony in Gradation: The Formula for Everything, 17th December 2018, https://www.haryadi.org/income-equality/

61. Sigit Haryadi. "Inequality of Human Development Index." Harmony in Gradation: The Formula for Everything, 17th December 2018, https://www.haryadi.org/inequality-of-human-development-index/

62. Sigit Haryadi. "Internet Service Equity." Harmony in Gradation: The Formula for Everything, 17th December 2018, https://www.haryadi.org/internet-service-equity/

63. Sigit Haryadi. "Linear Regression without Intercept." Harmony in Gradation: The Formula for Everything, 17th December 2018, https://www.haryadi.org/linear-regression-without-intercept/

64. Sigit Haryadi. "Modified Formula of Information Entropy." Harmony in Gradation: The Formula for Everything, 17th December 2018, https://www.haryadi.org/channel-cavity/

65. Sigit Haryadi. "Performance Simulation of 5G Cellular Network." Harmony in Gradation: The Formula for Everything, 17th December 2018, https://www.haryadi.org/performance-simulation-of-5g-cellular-network/

66. Sigit Haryadi. "Smart Estimation ver-H-1-0." Harmony in Gradation: The Formula for Everything, 17th December 2018, https://www.haryadi.org/smart-estimation-ver-h-1-0/

67. Sigit Haryadi. "Linear Regression with Intercept." Harmony in Gradation: The Formula for Everything, 17th December 2018, https://www.haryadi.org/linear-regression-with-intercept/ 